\title{
Basic Issues of Management in the Field of Public Security
}

\author{
Wojciech Franciszek Wiśniewski ${ }^{1}$ \\ ${ }^{1} \mathrm{PhD}$ student in Management, Warsaw School of Economics
}

\begin{abstract}
The issue of management in the area of public security is a subject under intensive research due to its importance for managing the security of the state. In a high standard manner, this problem was addressed in Poland in an organized way in the beginning of the 20th century. The management of public security is exercised by the authorities and public administration. The authorities set up the legal basis and introduce organizational solutions. Public administration is responsible for the full and effective organization of management in this type of safety. In the present paper, the Author presents basic management problems in the area of public security using several theoretical methods.
\end{abstract}

Key words - management, organization, society, security, public security

\section{INTRODUCTION}

The issues of public security management are not sufficiently researched. Hence the question: What is public security and how it should be managed? The key issue to be addressed before attempting to define the concept of management is to determine what an organization is. The Polish Language Dictionary presents three definitions (Sjp.pwn.pl, 2018):

- a group of people or countries having a fixed structure and acting together to achieve common goals;

- way of organizing something;

- organizing something.

From the point of view of the presented considerations, the second of the above will be applied in the further part of the work.

Management is also determined in multiple ways. Most often it is perceived as an art of implementing something through other people (Stoner, 1996). Management is understood as a process of planning, organizing, leading (initiating, stimulating, motivating) and controlling the activities of members of the organization and using all of its other resources to achieve the set goals (Stoner, 2018)(Stoner, 1996). In this context, planning should be perceived as a plan or logic usually based on the current procedure, not on premonition (Stoner, 1996). In

ASEJ - Scientific Journal of Bielsko-Biala School of Finance and Law

Volume 22, No 3 (2018), pages 5

DOI: $10.5604 / 01.3001 .0012 .7852$

Received 04 September 2018; Accepted 23 October 2018 contrast, organizing should be understood as coordinating human and material resources available to the organization (Stoner, 1996). Leadership is the way in which decision makers guide and influence their subordinates, leading them to perform the necessary tasks (Stoner, 1996). And finally, control, understood as the actions of decision makers (detecting obstacles and its remedies), ensuring that the organization aims at achieving the assumed goals (Stoner, 1996).

Since the first sentences of this paper highlight the connection between management and process, the question what is a process should be asked? The answer comes from L. Krzyżanowski, who believes that a process is a sequence (band, chain) of changes that take place in directly overlapping moments, intentionally distincted as a whole (Krzyżanowski, 1994). At the same time, he emphasizes that 'processes and events occur only in the real world; however, their entitativity is always dependent, because they must necessarily coexist with objects inside which, among which or around which they are made' (Kitler, 2007).

In the process of management, which is a social process, 'there are also states of things (changes) that are outside the sphere of human influence' (Kitler, 2007), which may lead to the conclusion that the process of managing safety 'also includes changes independent of the influence of one or many entities' (Kitler, 2007). Taking into account the above circumstances, one can conclude that the process of safety management includes 'a sequence of a specific type of changes, dependent or independent of the components of the safety management system occurring within this system or resulting from the relations connecting it with its surroundings' (Kitler, 2007).

In the era of dynamically occurring social changes, 'contemporary reality is becoming more and more complicated. Living conditions require many choices in life that allow people to open up opportunities for themselves and at the same time ensure the safety of other people. As the civilization develops, among others, through the development of technology, society has tried to reduce the risk in working processes, but still, it cannot be completely eliminated. Knowledge allows a person

Regular research paper: Published 30 October 2018

Corresponding author's e-mail: wfwisniewski@o2.pl

Copyright (C) 2018 This is an open access article distributed under the Creative Commons Attribution CC-BY-NC 4.0 License. 
to adopt rational solutions in crisis situations (...) with an acceptable level of risk' (Wiśniewski, Kozioł, and Falecki, 2017). Knowledge from various fields and disciplines, knowledge that can and should be used to effectively manage security, public security including. Hence the emerging needs addressed to science, education and didactics.

How to deal with the problems outlined above? The answer is simple: apply uncomplicated research methods. Therefore, during the preparation of this work, theoretical research methods were used, i.e. the analysis and synthesis. The method of analysis was used in literature studies of the subject, thanks to which, the basic problems that define the subject-matter scope of this work have been identified. This method also made it possible to determine the conditions of the process of managing public security. The method of synthesis was used to formulate conclusions referring to the issues of managing public security.

\section{II.PUBLIC SECURITY}

What is public security? The answer to this question seems quite straightforward on the surface. In reality this is a complex notion whose explanation should begin from the basics of security and only then move towards definition of public security. To explain the meaning of security is as difficult as to explain the essence of management mentioned earlier. Both terms are defined in many different ways and from various angles.

The origins of the word 'security', found in many languages (also in Polish), reflect the primal presence of threat over the feeling of safety and protection. in Polish language 'bezpieczeństwo' means 'without custody' in the sense of being deprived of sufficient protection (Zięba, 1997). The English word 'security' having its source in Latin 'sine cura', literally means exactly the same as in Polish” (Zięba, 1997). The term 'security' embraces the following:

- Lack of threat, peace, certainty;

- Major need of an individual human being and of entire social groups (Zięba, 1989);

- Continuous social process within which active entities try to adapt mechanisms that assure the feeling of security (Kukułka, 1982).

It is more than necessary to recall here the famous pyramid of human needs developed by Abraham Harold Maslow (Maslow and Murphy, 1954). From the bottom of the hierarchy upwards, the needs are: physiological, safety, love and belonging, esteem and self-actualization. Needs lower down in the hierarchy must be satisfied before individuals can attend to needs higher up. As it can be observed the need of security is right above the most basic physiological needs.

One of the identification criteria of security and security management is 'process' which is a common identification element of all considerations presented so far. Thus, 'security' is perceived as 'a continuous activity of individuals, local communities, states and international organizations in creating the desired level of security' (Jakubczak and Flis, 2006). In general social sense 'security satisfies the following needs: existence, survival, certainty, stability, unity, identity, independence, protection of living standards. Security being the major need of individuals and groups of human beings, is at the same time the basic need of states and international systems. Lack of security triggers anxiety and feeling of threat' (Zięba, 1989).

The complexity of interpretations of the term 'security' leads to the situation in which multiplicity of different types of security coexists in various typologies (Jakubczak, 2006). Generally speaking, it can be assumed that a common feature of all typologies is seeing security in three fundamental dimensions: subjective, objective and processual (Wawrzusiszyn, 2012) (also known as prospective or functional). Special attention should be paid to the subjective approach in which 'security refers to the participants of social life whose number is constantly rising (individuals, social groups, nations, countries, non-state participants of international relations and international community)'. In subjective scope there is a departure from the state-centred perception of security resulting from the necessity to expand the catalogue of protected values (...). In the objective scope, security refers to various layers and extension of:

- the catalogue of protected values,

- the scope of resources ad methods of the security policy,

- the spatial vision of security of nations' (Wawrzusiszyn, 2012).

It is time to define the notion of 'society'. K. Loranty observes that 'in literature the term society does not make a clear theoretical sense. This term is very often used to cover all forms of social life which are juxtaposed with the category of an individual'(Loranty, 2003). Therefore, K. Loranty proposes to treat 'society' as a certain entirety consisting of three basic constituents (Turowski, 2000):

- objective conditions for life and survival;

- social structure;

- culture created by this social group.

Society is also a certain demographic aggregate. Biological reproductive functions are supported by socialization processes, social control processes and various institutions regulating reproduction. Even such personal and intimate activities as reproduction are not for the exclusive use of an individual, although individuals may think so. Demographic transformations are a direct reflection of social changes. In light of the theory of demographic passage, in human demographic patterns two opposing tendencies may be observed: biological survival and maintaining the balance with respect to the environment. In accordance with this theory, each society under modernization process experiences demographic passage i.e. radical, lasting and irreversible decrease in the mortality and fall in the birth rate (Loranty, 2003).

For the sake of transparency of deliberations presented here, it is necessary to adopt a precise conceptual apparatus. Therefore it should be observed that public security is of polysemantic nature and is closely related to public order, balance and laying the foundations for the existence of the society (Fehler, 2010). A. Trzpil argues that this issue may be perceived from a wider and narrower perspective. In the wider 
perspective it is necessary to conduct analysis on social groups and mutual relations between them within the scope of international communities; in the narrower perspective, the emphasis should be on social structure, conflicts, integration and disintegration processes that impact social order and relations between individuals (Trzpil, 2006). Public security understood in this way 'is directly related to the main objectives of social policy which are:

- removing disparities in living and working conditions through satisfaction of needs of different age groups;

- offering equal opportunities with respect to enjoying citizens' rights;

- removing social inequalities;

- safeguarding against life risks' (Auleytner and Głąbicka, 2000).

For the needs of the present paper it was assumed that public security 'is a state of security which guarantees not only continuing existence and survival of the nation but also its development. This state of security is the outcome of the activities of the State (as it was established to provide security to the people) manifesting, most of all, in a specific social policy implemented by the administration. The state of security is also impacted by spontaneous social processes being outside the administration mandate or processes unintentionally generated by the activities of the State authority. The said processes are either the consequence of the very nature of social life or the consequence of failing to embrace this nature in the creation of social transformations in a State' (Auleytner and Głąbicka, 2000)

\section{III.DETERMINANTS OF MANAGEMENT IN THE FIELD OF PUBLIC SECURITY}

Even superficial analysis of the issue of security management allows to formulate a thesis that change is the basis of management. The holistic approach allows for security management in the area of public security 'as a separate unity to be seen in a wider perspective i.e. in the aspect of co-existing among other equal or superior beings. Thus, the typology of determinants may embrace internal and external conditioning (factors) and mutual relations between these two. Internal factors (...) include material, energetic, social and cultural conditioning, whereas, internal consist of the same factors which constitute the environment of the system and impact the system directly and indirectly' (Kitler, 2007).

The internal scope of management in the field of public security includes also:

- government and public administration organs;

- people of different views and opinions;

- entrepreneurs;

- social and political organizations;

- non-governmental organizations (Kitler, 2007).

As far as the role of government and public administration organs is concerned, it is necessary to emphasize their mission with respect to the society (Tyburska and Nepelski, 2008). The mission can be seen in two layers of security; the first is about protection of 'national values and vital interests against potential threats' (Jakubczak and Flis, 2006), the other refers to the creation of $(\ldots)$ 'conditions for unrestrained development, and standing up to challenges facing the nation such as volatility, unpredictability and progress of civilization' (Jakubczak and Flis, 2006).

Speaking of public authorities, it is important to mention the State as a political organization. One of the basic motives behind the drive of individuals and communities to form a State was the desire to satisfy the need of security. The role of the State, somehow by its nature, is to serve individuals and whole social groups. Therefore, the social, economic and political space should be organized in such a way to create conditions of safe and comfortable existence for all entities that constitute the State. Generally speaking, everything the State does for the sake of the society should aim for the good of the society, providing conditions for life, survival and development. The Sate, while conducting international, internal, economic or educational policy has in mind the well-being of people it represents" (Loranty, 2003). Such activity of the State 'is perceived and felt by individuals and social groups, this activity acquires a subjective meaning and is evaluated from the perspective of interests of individuals, groups or the entire nation (...). In this sense, each activity of the State creates situations which contribute to the feeling of security, assurance and optimism, or alternatively, threat, uncertainty, frustration and dispirit. Such subjective judgements impact the reaction of the society to the activities undertaken by the State' (Loranty, 2003).

Public administration undoubtedly impacts managing in the field of public security. Administration is a very wide and diversified notion with respect to its various functions and areas of activity. The most frequently encountered division of administrative function differentiates between interfering function, service function and infrastructure function. Another division of functions of administration in public security was proposed by $\mathrm{H}$. Izdebski and M. Kulesza who differentiate between: the maintenance of public order function, the rationing function, the service to the citizens function and performing ownerships rights and management rights (Izdebski and Kulesza, 1999).

Maintenance of public order consists of performance of tasks aimed at protecting public order and collective security, whereas the rationing function regulates the number of issued permits. For many years these were the main functions of state authorities which were upheld by means of appropriate instruments: orders, interdicts and permissions to conduct activity, but also with help of law enforcement agencies. Orders ad interdicts are issued by the public authority to make the members of the community respect the law. It is the first step towards imposing lawful behaviour upon citizens. If the law is not obeyed and broken, the citizens may be punished.

It should be emphasized that the decision about what is appropriate in a particular situation belongs to a relevant organ of administration. Permits for conducting activity related to protection of public order and collective security are issued by relevant organs of public administration after fulfilling legally required conditions. If an applicant fulfills all conditions required by law, the organ is then obliged to issue the permit. 
Public administration organ may also make use of the institution called the administrative discretion. 'The essence of construction of administrative discretion is flexibility, intentionally provided for in the act, to shape the content of legal effects by a public administration organ. The legislator prejudges that in certain situations, (...), the administrative organ may take the role of the legislator and independently adjudicate on the content of a legal effect and through this adjudication assure provision of the public weal to an optimum degree (statutorily individualized value)' (Cieślak, Lipowicz and Niewiadomski, 2013).

Multiplicity of institutions responsible for public security functioning within administration calls for such organization of the institutions which would guarantee efficient performance of entrusted tasks. There must be a certain kind of a coordinating instrument, which will serve as a mechanism of responsibility for the efficiency of performed tasks.

In the contexts of deliberations made so far, it is important to emphasize that the social conditioning of security is of subjective nature. 'Regarding the complexity of social problems, there are such factors as: private interests, public interests, as well as national and international interests; legal norms; social conflicts; multiplicity of social positions and roles; uneven standards of living; formal and informal social impact; national distinctness of societies; quantitative and qualitative diversity; mutual obligations - ties that connect across boundaries and others. Special attention must be paid here to the issue of challenges and threats accompanying human activity or resulting from the forces of nature' (Tyburska and Nepelski, 2008).

For the considerations put forward in the paper it is important to highlight that internal conditioning of management in public security also embraces the law factor. Law 'formally sanctions the functioning of a State and almost all entities within its borders (national law), it regulates the functioning of states and international entities within international relations (international law)' (Tyburska and Nepelski, 2008). It comes without saying that the importance of law for each state is huge, 'thanks to the norms formulated by relevant organs the rules of procedure in provision of public security are determined (...), the law also governs the ruling class, economic market, social organizations and individual citizens. The intrinsic relationship between the State and its legal system plays a vital role in the organization of activities undertaken by the State activities and by entities functioning within the territory of the State. The efficiency of the functional construction of the State and its organizational constituents depends on the nature and scope of the law (...), one of such constituents is the society' (Tyburska and Nepelski, 2008)

\section{IV.CONCLUSIONS}

Any theoretical considerations made with respect to management in the field of public security 'only make sense when they are referred to a specific concept of a human being and the society. For some time now, experts have been unanimous so as to the fact that an individual living outside the society will not be capable of developing a personality as a social and moral being. A human being isolated from the society does not exist. The society, in turn, is worth as much as it facilitates personal development of an individual. This mutual determination makes the characterization of a human being extremely difficult, the same is true about the group of human beings i.e. the society. It is impossible to describe society without taking into account the essence and nature of an individual human being' (Loranty, 2003).

Management in public security seems to be one of the most important sectors of management when it comes down to security of the State. Public security directly depends on a number of factors, most of all, on the efficiency of authority organs and public administration. This efficiency relies on appropriate legislation in force and is supported by scientific and educational activity. So, it should be emphasized once more that internal conditioning plays a vital role in the management of public security. The analysis of literature on the topic shows that in the nearest future the situation will remain unchanged.

\section{V.REFERENCES}

Kitler, W. (2007). Istota, właściwości i ogólne determinanty procesu zarządzania bezpieczeństwem narodowym RP. In: T. Jemioło, ed., Zarządzanie bezpieczeństwem narodowym vol. II. Warszawa: Akademia Obrony Narodowej, p.16-18.

Tyburska, A. and Nepelski, M. (2008). Ochrona infrastruktury krytycznej. Szczytno: Wyższa Szkoła Policji, pp.8-9,18.

Jakubczak, R. and Flis, J. (2006). Bezpieczeństwo narodowe Polski w XXI wieku. Wyzwania i strategie. Warszawa: Bellona, p.22.

Izdebski, H. and Kulesza, M. (1999). Administracja publiczna. Warszawa: PWN, p.85.

Cieślak, Z., Lipowicz, I. and Niewiadomski, Z. (2013). Prawo administracyjne. Warszawa: LexisNexis, pp.85-86.

Loranty, K. (2003). Bezpieczeństwo spoleczne Rzeczypospolitej Polskiej. Warszawa: Akademia Obrony Narodowej, pp.8, 24, 97.

Jakubczak, R. (2006). Bezpieczeństwo narodowe Polski w XXI wieku. Wyzwania i strategie. Warszawa: Bellona, p.457.

Wawrzusiszyn, A. (2012). Wybrane problemy transgranicznego bezpieczeństwa Polski. Warszawa: DIFIN, p.16.

Turowski, J. (2000). Socjologia. Wielkie struktury społeczne,. Lublin: Towarzystwo Naukowe KUL, pp.52-53.

Fehler, W. (2010). Pokój społeczny w mechanizmie bezpieczeństwa wewnętrznego polski pierwszej dekady XXI wieku. In: W. Kaczmarek, R. Socha and J. Grzyb, ed., Edukacja dla bezpieczeństwa młodzieży gimnazjalnej i ponadgimnazjalnej. Ełk: Mazurski Ośrodek Doskonalenia Nauczycieli w Ełku, p.10.

Trzpil, A. (2006). Pokój społeczny jako podstawa twórczego ładu społecznego. In: W. Leżańska and T. Jałmużna, ed., Pokój jako przedmiot badań społecznych i pedagogicznych. Łódź, pp.39-40.

Auleytner, J. and Głąbicka, K. (2000). Polityka spoleczna - pomiędzy opiekuńczościa a pomocniczością. Warszawa, pp.17-18.

Auleytner, J. and Głąbicka, K. (2000). Polityka społeczna - pomiędzy opiekuńczością a pomocniczością. Warszawa, pp.17-18.

Cieślak, Z., Lipowicz, I. and Niewiadomski, Z. (2013). Prawo administracyjne. Warszawa: LexisNexis, pp.85-86

Fehler, W. (2010). Pokój społeczny w mechanizmie bezpieczeństwa wewnętrznego polski pierwszej dekady XXI wieku. In: W. Kaczmarek, R. 
Socha and J. Grzyb, ed., Edukacja dla bezpieczeństwa mtodzieży gimnazjalnej $i$ ponadgimnazjalnej. Ełk: Mazurski Ośrodek Doskonalenia Nauczycieli w Ełku, p.10.

Izdebski, H. and Kulesza, M. (1999). Administracja publiczna. Warszawa: PWN, p.85.

Jakubczak, R. (2006). Bezpieczeństwo narodowe Polski w XXI wieku. Wyzwania i strategie. Warszawa: Bellona, p.457.

Jakubczak, R. and Flis, J. (2006). Bezpieczeństwo narodowe Polski w XXI wieku. Wyzwania i strategie. Warszawa: Bellona, p.22.

Jakubczak, R. and Flis, J. (2006). Bezpieczeństwo narodowe Polski w XXI wieku. Wyzwania i strategie. Warszawa, p.15.

Kitler, W. (2007). Istota, właściwości i ogólne determinanty procesu zarządzania bezpieczeństwem narodowym RP. In: T. Jemioło, ed., Zarzadzanie bezpieczeństwem narodowym vol. II. Warszawa: Akademia Obrony Narodowej, p.16-18.

Kitler, W. (2007). Istota, właściwości i ogólne determinanty procesu zarządzania bezpieczeństwem narodowym RP,. In: T. Jemioło, ed., Zarzadzanie bezpieczeństwem narodowym, praca badawcza. Warszawa: Akademia Obrony Narodowej, p.16.

Krzyżanowski,, L. (1994). Podstawy nauk o organizacji $i$ zarządzaniu. Warszawa, p. 121.

Kukułka, J. (1982). Międzynarodowe stosunki polityczne,. Warszawa: Państwowe Wydawnictwo Naukowe, p.31.

Loranty, K. (2003). Bezpieczeństwo spoleczne Rzeczypospolitej Polskiej. Warszawa: Akademia Obrony Narodowej, pp.8, 24, 97.

Maslow, A. and Murphy, G. (1954). Motivation and personality. New York: Harper \& Brothers, p.34.

Sjp.pwn.pl. (2018). Stownik języka polskiego PWN. [online] Available at: http://sjp.pwn.pl/ [Accessed 12 Sep. 2018].

Stoner, J. (1996). Kierowanie. Warszawa: Państwowe Wydawnictwo Ekonomiczne, p.23-24.

Trzpil, A. (2006). Pokój społeczny jako podstawa twórczego ładu społecznego. In: W. Leżańska and T. Jałmużna, ed., Pokój jako przedmiot badań społecznych i pedagogicznych. Łódź, pp.39-40.

Turowski, J. (2000). Socjologia. Wielkie struktury społeczne,. Lublin: Towarzystwo Naukowe KUL, pp.52-53.

Tyburska, A. and Nepelski, M. (2008). Ochrona infrastruktury krytycznej. Szczytno: Wyższa Szkoła Policji, pp.8-9,18.

Wawrzusiszyn, A. (2012). Wybrane problemy transgranicznego bezpieczeństwa Polski. Warszawa: DIFIN, p.16.

Wiśniewski,, B., Kozioł, J. and Falecki, J. (2017). Podejmowanie decyzji w sytuacjach kryzysowych,. Szczytno: Wyższa Szkoła Policji, p.7.

Zięba, R. (1989). Pojęcie i istota bezpieczeństwa państwa w stosunkach międzynarodowych. Sprawy międzynarodowe, 10, pp.50-51.

Zięba, R. (2018). Kategoria bezpieczeństwa w nauce o stosunkach międzynarodowych. In: D. Bobrow, E. Haliżak and R. Zięba, ed., Bezpieczeństwo narodowe i międzynarodowe u schytku XX wieku. Warszawa: SCHOLAR, p.3 